University of Nebraska - Lincoln

DigitalCommons@University of Nebraska - Lincoln

\title{
Feed management practices to reduce manure phosphorus excretion in dairy cattle
}

E. Kebreab

University of California - Davis, ekebreab@ucdavis.edu

A. V. Hansen

University of California - Davis

B. Leytem

USDA-ARS

Follow this and additional works at: https://digitalcommons.unl.edu/usdaarsfacpub

Kebreab, E.; Hansen, A. V.; and Leytem, B., "Feed management practices to reduce manure phosphorus excretion in dairy cattle" (2013). Publications from USDA-ARS / UNL Faculty. 1483.

https://digitalcommons.unl.edu/usdaarsfacpub/1483

This Article is brought to you for free and open access by the U.S. Department of Agriculture: Agricultural Research Service, Lincoln, Nebraska at DigitalCommons@University of Nebraska - Lincoln. It has been accepted for inclusion in Publications from USDA-ARS / UNL Faculty by an authorized administrator of DigitalCommons@University of Nebraska - Lincoln. 


\title{
Feed management practices to reduce manure phosphorus excretion in dairy cattle
}

\author{
E. Kebreab ${ }^{1 \dagger}$, A. V. Hansen ${ }^{1}$ and A. B. Leytem ${ }^{2}$ \\ ${ }^{1}$ Department of Animal Science, University of California, Davis, Davis, CA 95616, USA; ${ }^{2}$ USDA-ARS, Kimberly, ID 83341, USA
}

\begin{abstract}
Phosphorus $(P)$ is an essential mineral that needs to be supplied in sufficient quantities for maintenance and growth and milk production in dairy cattle. However, over $60 \%$ of the $P$ consumed can be excreted in faeces with a potential to cause environmental pollution. Concern over higher levels of $P$ in intensively managed livestock systems has led to legislation such as the Water Framework Directive in the European Union. In this manuscript, several methods of reducing $P$ pollution are discussed. A major source of environmental $P$ pollution has been overfeeding P mainly due to addition of 'safety margin' over the animal's requirement and concerns related to fertility. Matching the animal's requirement and feeding in groups so that animals at the same physiological status are fed according to their requirement has a potential to reduce $P$ excretion significantly. $P$ can also be reduced by matching available $P$ with the metabolizable energy content of the diet because more $P$ can be incorporated into milk when $P$ is utilized by rumen microbes, which are limited by energy. Plants contain phytate bound $P$ that need to be broken up before they can be absorbed by the animal. Although ruminants can digest phytate, use of phytase enzyme could help either directly by acting on phytate $P$ or improvement of feed digestibility. Pasture management can lead to improved nutrient cycling, particularly if the soil is deficient in P. However, overfertilizing pasture could result is higher runoff of dissolved reactive $P$. Management practices that leave adequate forage residue on the surface such as rotational grazing will improve infiltration and decrease runoff, reducing nutrient losses.
\end{abstract}

Keywords: Phosphorus, dairy cattle, nutrient pollution

\section{Introduction}

Phosphorus $(\mathrm{P})$ is an essential macro-mineral necessary for many body functions and needs to be supplied in sufficient quantities to optimize animal performance. Phosphorus and calcium are the two most plentiful minerals in ruminants (Kebreab and Vitti, 2005). Phosphorus constitutes $1 \%$ of the total BW, $80 \%$ of which is found in the bones. The remaining $20 \%$ is distributed in body cells and is involved in maintaining the structural integrity of cells and in intracellular energy and protein metabolism. Most of the calcium in ruminants (99\%) is found in bones and teeth; the remaining $1 \%$ is distributed in various soft tissues (McDowell, 1992).

Globally, there has been an increase in public concern about potential environmental damage originating from livestock production systems. For example, increased specialization and concentration of livestock and crop production have led to the net export of nutrients from major crop producing areas to areas with a high concentration of animal agriculture. Livestock excrete large amount of $P$ in faeces because $<40 \%$ of $P$ consumed may be utilized depending on $P$ availability, efficiency of feed conversion and the

\footnotetext{
† E-mail: ekebreab@ucdavis.edu
}

amount of $\mathrm{P}$ consumed in excess of the animal's requirement. Therefore, the majority of $P$ brought on to the farm in feed stays on the farm, rather than being exported in meat or milk.

In addition, inorganic $P$ is a finite resource, which needs to be used wisely. Supplemented inorganic $P$ not used by the animal is primarily excreted in faeces. This faecal $P$, once land applied, can then lead to $\mathrm{P}$ accumulation in the soil, leach into groundwater or cause eutrophication of surface waters due to $P$ transport in runoff (Tamminga, 1996). The objective of this study is to review mitigating options to reduce $P$ excretion in dairy cattle.

\section{Management practices to reduce phosphorus excretion}

Feed management practices that reduce $P$ excretion in cattle can be broadly divided in to two categories: (1) improving or optimizing $P$ availability in feed and (2) increasing efficiency of livestock through increased $P$ incorporation in product or faster growth (Kebreab et al., 2012). Reduced overfeeding by matching animal $P$ requirement with available $P$ in the diet, ration formulation methods, feeding animals in groups according to their physiological state, and grazing management will be discussed in detail. 


\section{Reduced overfeeding}

In ruminants, P fed in excess of animal requirements is excreted, making reduced overfeeding a powerful tool to decrease the $\mathrm{P}$ content of manure. The most common reason for overfeeding dietary $P$ in dairy cattle is the perception that high $\mathrm{P}$ diets improve reproductive performance. Although severe $P$ deficiency may impair reproductive performance, there is no research to suggest a benefit from feeding $P$ to dairy cows in excess of NRC (2001) requirements. Satter and Wu (1999) reviewed studies with 785 lactating cows fed diets low in $\mathrm{P}(0.32 \%$ to $0.39 \% \mathrm{P})$ or high in $\mathrm{P}(0.39 \%$ to $0.61 \% \mathrm{P})$ and found that dietary $\mathrm{P}$ has no effect on days to first oestrus, days open, services per conception, days to first insemination or pregnancy rate. There are also other factors that have led farmers to overfeed $P$. These include compensation (safety margin) for suspected undetected variation in the $P$ content of feeds, and inconsistencies between NRC (2001) requirements and the nutritional advice farmers receive.

Several surveys have shown that cattle are still been fed in excess of requirement. Kebreab et al. (2008) showed that a reduction of $P$ in the diet from $0.41 \%$ to $0.35 \%$ of dry matter (DM) during mid to late lactation would save producers $\sim$ \$20/cow per year. This calculation is based on assuming all cost savings are from reduced inorganic $P$ supplementation. However, if feeds low in $\mathrm{P}$ are used, some supplementation might be necessary to meet the $P$ requirement. Valk et al. (2002) have suggested that much lower amounts of $P(0.26 \%$ to $0.29 \%$ P of DM) are sufficient to meet the cow's requirement. However, the cows in the Valk et al. (2002) experiment had an average annual milk production of $\sim 9000 \mathrm{~kg}$, which is lower than normally expected levels of above $10000 \mathrm{~kg}$.

Phase feeding is a concept that is based on the premise that the population requirement for $\mathrm{P}$ (as well as other essential nutrients) changes during the stage of growth, lactation and gestation. This can be exploited by feeding multiple diets where each of the diets provides optimal nutrient densities at the midpoint of each sub-interval (phase). According to NRC (2001), the P requirement of Holstein cows depends on the production level of the animal (Table 1). Therefore, a significant amount of $P$ can be saved by adjusting the level of $P$ supplemented to match the physiological status of the cows. In lactating ruminants, opportunity exists to reduce $\mathrm{P}$ excretion by accounting for the $P$ released through the normal catabolism of bone that occurs in early lactation (Knowlton et al., 2010). Phosphorus release from bone during early lactation provides a readily available source of $P$ to meet the needs for maintenance and milk yield. Ternouth (1990) suggested that beef steers fed P-deficient diets could mobilize up to $30 \%$ of bone mineral, or $6 \mathrm{~g} /$ day of $P$, meeting about half of their dietary requirement. Satter et al. (2002) extended this estimate to a $600 \mathrm{~kg}$ lactating cow, and estimated that as much as 600 to $1000 \mathrm{~g}$ of $P$ could be mobilized in early lactation. Supporting this, Knowlton and Herbein (2002) observed that apparent mobilization of $P$ from body reserves may meet a significant proportion of the dairy cow's net need for $P$ during early lactation. Assuming $P$ balance reflects $P$ resorption from bone, cows mobilized up to $25 \mathrm{~g} /$ day of $P$ from bone in the first 3 to 5 weeks of lactation. The requirement for absorbed $\mathrm{P}$ in early lactation totals 45 to $70 \mathrm{~g} /$ day, depending on milk yield (NRC, 2001).

Increasing dietary $\mathrm{P}$ levels with $\mathrm{P}$ minerals not only leads to greater concentrations of total faecal $P$, but more importantly, increases the amount of water-soluble P (Dou et al., 2002), which is most susceptible to loss into the environment. Dou et al. (2001) showed that reducing dietary $P$ decreased the water-soluble fraction of faecal $P$, which could be as much as $70 \%$ of the total $P$ in faeces, which is comparable to the $64 \%$ reported by Toor et al. (2005). Wu et al. (2000) reported that cows fed lower P $(4.0 \mathrm{~g} / \mathrm{kg} \mathrm{DM} \mathrm{v}$. $4.9 \mathrm{~g} / \mathrm{kg} \mathrm{DM}$ ) excreted $23 \%$ less in faeces and indicated that dairy cows conserve $P$ by minimizing faecal and urinary $P$ excretions if fed lower $P$ diets. Kebreab et al. (2005b) showed that diets can influence the nature and solubility of $P$ in the faeces and that it may be possible to improve management of $P$ outputs from dairy farms. The authors noted that grass silage-based diets tend to produce slightly higher overall levels of $P$ output than urea treated whole crop wheat diets, although as a proportion of intake, relatively higher values were found on whole crop wheat diets. Cows fed grass silage-based diets had lower water soluble $\mathrm{P}$ in faeces compared with those fed whole crop wheat diets. Therefore, reducing inorganic $P$ supplementation will not

Table 1 Phosphorus requirements for Holstein cows (600 kg BW) with varying DMI and milk yield (NRC, 2001)

\begin{tabular}{|c|c|c|c|c|c|c|c|c|c|c|c|c|}
\hline \multirow[b]{3}{*}{ DMI (kg/day) } & \multicolumn{6}{|c|}{ Milk yield (kg/day) } & \multicolumn{6}{|c|}{ Milk yield (kg/day) } \\
\hline & 30 & 32 & 34 & 36 & 38 & 40 & 30 & 32 & 34 & 36 & 38 & 40 \\
\hline & \multicolumn{6}{|c|}{ Absorbed $\mathrm{P}$ requirement (g/day) } & \multicolumn{6}{|c|}{ Dietary $\mathrm{P}$ requirement $\left(\%\right.$ of diet $\mathrm{DM}^{\mathrm{a}}$ ) } \\
\hline 21.8 & 49 & 51 & 52 & 54 & 56 & 58 & 0.35 & 0.36 & 0.37 & 0.39 & 0.40 & 0.41 \\
\hline 22.5 & 49 & 51 & 53 & 55 & 57 & 58 & 0.33 & 0.34 & 0.35 & 0.37 & 0.38 & 0.39 \\
\hline 23.2 & 50 & 52 & 54 & 56 & 57 & 59 & 0.32 & 0.34 & 0.35 & 0.36 & 0.37 & 0.38 \\
\hline 23.9 & 51 & 53 & 54 & 56 & 58 & 60 & 0.32 & 0.33 & 0.34 & 0.35 & 0.36 & 0.38 \\
\hline 24.6 & 52 & 53 & 55 & 57 & 59 & 61 & 0.31 & 0.32 & 0.34 & 0.35 & 0.36 & 0.37 \\
\hline 25.3 & 52 & 54 & 56 & 58 & 60 & 61 & 0.31 & 0.32 & 0.33 & 0.34 & 0.35 & 0.36 \\
\hline
\end{tabular}

$\mathrm{BW}=$ body weight; $\mathrm{DMI}=$ dry matter intake; $\mathrm{DM}=$ dry matter.

aShaded cells indicate dietary P concentrations based on NRC-predicted DMI for the specified. 
only lead to more efficient utilization of $P$ (i.e. decrease the total amount of $P$ excreted) but also decrease the excretion of water-soluble $P$, which is a greater concern from a water quality perspective.

\section{Energy status of the animal}

Kebreab et al. (2005a) conducted two experiments in which grass silage was used in conjunction with a series of different concentrate types designed to examine the effect of carbohydrate source, protein level and degradability on total dietary $P$ utilization with emphasis on $P$ pollution. The authors reported that dairy cattle excreted up to $15 \%$ less $P$ when fed slow degradable starch sources compared with feed with high degradable starch content (Figure 1). This is because slow release of energy leads to higher utilization of nutrients, including $\mathrm{P}$ by rumen microbes. They also observed that increasing $P$ intake above $68 \mathrm{~g} /$ day resulted in a significant increase in faecal $P$ output without an improvement in lactational performance. Hill et al. (2008) developed a mathematical model to understand $\mathrm{P}$ regulation and homeostasis in the dairy cow. Simulations using the model showed that efficiency of utilizing $P$ increased when the energy content of the diet increased due to more $\mathrm{P}$ incorporation in milk.

\section{Enzymes}

Plants (predominantly grains) used as animal feed mostly store their P as phytate (myo-inositol hexakisphosphate), which is poorly available to monogastric animals, but ruminants are more effective in degrading phytate (Knowlton et al., 2007). Phytate $P$ can be converted to lower inositol phytate or inorganic $P$ that is easily digested by animals using an enzyme called phytase, which microbes in the rumen also produce. Microbial phytase can be added to diets to increase availability of phytate bound P. The activity of phytase depends mainly on $\mathrm{pH}$, temperature, dose and diet composition (Kincaid et al., 2005). For example, Kebreab et al. (2005b) reported that

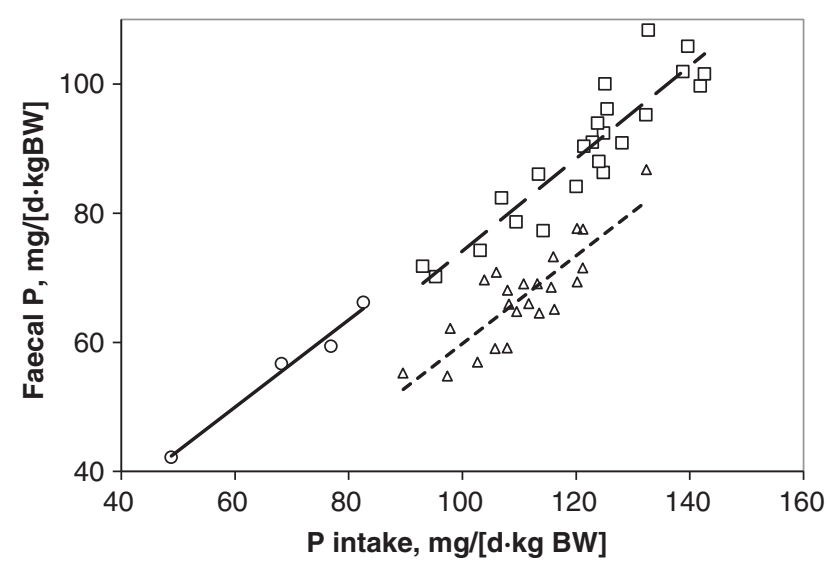

Figure 1 Relationship between $\mathrm{P}$ intake $(\mathrm{mg} /($ day $\cdot \mathrm{kg} \mathrm{BW}))$ and faecal $P(\mathrm{mg} /($ day $\cdot \mathrm{kg} \mathrm{BW}))$ in lactating ewes (0) and dairy cows fed diets with either low $(\square)$ or high $(\Delta)$ metabolizable energy content (Adapted from Kebreab et al., 2005a). BW = body weight. phytate digestibility was lower on the whole crop wheat based diets compared with grass silage probably due to the presence of whole wheat grains that were not adequately digested. The authors observed that a large part of phytate $P$ was hydrolysed in the rumen with further hydrolysis in the post ruminant tract. A study by Knowlton et al. (2007) showed $7 \%$ to $17 \%$ improved P digestibility when a mix of phytase and cellulose was fed to lactating cows, indicating that exogenous phytase may be beneficial for improving $P$ efficiency in the cow and reducing $P$ excretion. Hill et al. (2008) using a model describing phytate degradation in the rumen and hindgut, microbial use of $P$, intestinal digestion of non-phytate organic $\mathrm{P}$, absorption of inorganic $\mathrm{P}$ and recycling of blood $P$ into the rumen via saliva showed that changing $P$ fractions such as phytate was less important than $P$ concentration for amount of $P$ excretion. They concluded that total $P$ excreted was not very sensitive to altering phytase activity, but it did affect $\mathrm{P}$ balance.

Because of differences in $\mathrm{pH}$ of the digestive tract of ruminants and monogastric animals, different types of phytases are required for ruminants. It is possible that the benefit of the phytases is an overall improvement in diet digestibility rather than its action on phytate. Continued development of phytase through improved understanding of its ability to breakdown organic $P$ may produce more effective classes of phytases, which will decrease the faecal P excretion.

\section{Grazing cattle}

Cattle feeding entirely on forages need supplementation of $P$ to cover the daily requirement and to avoid $P$ deficiency often caused by P deficiency in soils and plants (Karn, 2001). To determine the precise $P$ requirement of grazing dairy cattle, it is crucial to know the P content and availability in the forage species being grazed besides the characteristics of the animal (e.g. stage of lactation), because excess supplementation of $P$ to the animal will increase the faecal $P$ excretion and deficiencies will affect productivity. Supplementation of $\mathrm{P}$ for grazing animals can be provided in several ways, for example, direct feeding in water, free-choice as a lick/mineral stone or loose in feeder, hand fed in a feed mixture, through a drench or by proper fertilization of the pasture.

\section{Pasture improvement}

Livestock grazing including foraging, treading and defecation can have great impact on soil and water quality. Treading makes the soil surface more compact and causes accumulation of nutrients in and on the soil. This results in structurally poor soil, lower infiltration rates, and enhanced runoff which lead to $P$ transport to surface water.

Fertilization of natural pastures that are deficient in $\mathrm{P}$ has been shown to improve $P$ status of the soil through faeces (Del Pino and Hernández, 2002). The authors observed that $P$ in faeces from pastures fertilized with 30 and $60 \mathrm{~kg}$ of $\mathrm{P}_{2} \mathrm{O}_{5} / \mathrm{ha}$ in Uruguay was higher than natural pastures and contained $61 \%$ water soluble P. In England, fertilizer 


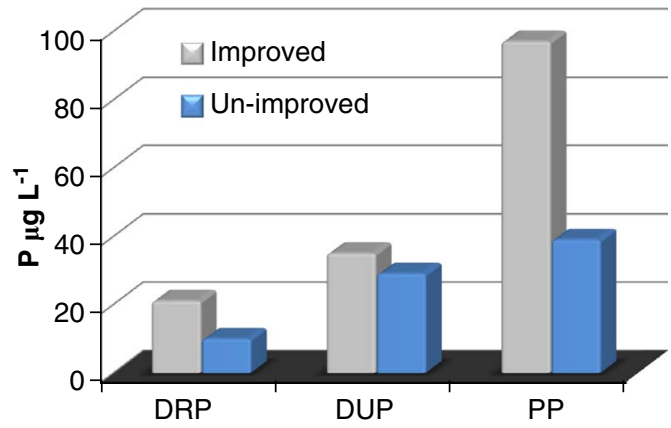

Figure 2 Daily flow and concentrations of dissolved reactive $P(D R P)$, dissolved unreactive $P(D U P)$ and particulate $P(P P)$ in streams draining unimproved and improved land.

$P$ inputs to improve natural pasture maintained available $P$ concentrations in the soil $(0$ to $7.5 \mathrm{~cm})$ at optimum levels for grass production (16 to $25 \mathrm{mg} / \mathrm{l})$, while unimproved areas contained only 4 to $6 \mathrm{mg} / \mathrm{l}$ of available $P$ (Withers et al., 2007). The authors found a direct link between pasture improvement, soil $P$ accumulation and increased $P$ fluxed in the upland stream as concentrations of dissolved reactive $P$ (DRP) increased $100 \%$ in catchment of improved compared to unimproved pasture (Figure 2). Although the increase is not desirable, Withers et al. (2007) suggested that a catchment with nearly $50 \%$ improved land could still meet standards for good water quality in upland streams. Overfertilization of pastures or overapplication of manures to pasture can also lead to leaching of $P$ and losses to groundwater in coarse textured soils.

\section{Rotational grazing}

In management-intensive grazing systems, cattle graze one section of a larger pasture for a short period, often only 12 to $24 \mathrm{~h}$ on each section. The rotation of the animals through the sections allows the grazed sections to regrow before re-grazing and because the grazing period in each section is very short, severe treading and overgrazing is avoided resulting in reduced $P$ losses. A survey the North-eastern United States showed that 13\% of the dairy producers use this method with the number of farms using the system increasing (Winsten et al., 2010). The system was typically used by small or medium size herds (50 to 70 animals), because it is labour-intensive. Producers using the system had better economic and environmental advantages than producers using traditional systems for dairy cattle (Winsten et al., 2010).

Haan et al. (2006) compared the effect of rotational stocking to a residual sward height of 5 or $10 \mathrm{~cm}$ with continuous stocking and ungrazed pastures. The authors reported that rotational grazing reduced total P load in runoff $64 \%$. Rotational grazing also improved infiltration and protected the soil surface from raindrop impact, reducing $\mathrm{P}$ losses.

\section{Conclusions}

There are several way of reducing $\mathrm{P}$ excretion and runoff into surface waters. One of the most powerful methods to reduce $\mathrm{P}$ excretion is reduced overfeeding and matching $\mathrm{P}$ supplementation to animals' requirement. This can be done by cutting 'safety' margins and feeding animal in groups according to their physiological status. Overall diet and perhaps phytate bound $\mathrm{P}$ can be improved through addition of phytases, although more work need to be done in this area to quantify the effects of adding phytases, including types and application doses. In pasture-based management systems, overfertilization of grasslands may cause higher runoff of DRP to upland streams. However, mitigation options such as rotational grazing would help reduce $P$ runoff.

\section{Further information}

The Dairy Solutions Symposium is a biennial event that covers a wide variety of themes and topics of relevance and importance to the dairy industry. The aim is to provide high level, up-to-date information and research to dairy professionals, technologists and scientists. In 2012, the theme addressed the biggest challenge facing all those involved in dairy production: optimizing production efficiency while lowering environmental impact. For more information, please visit www.dairycowsolutions.com or contact dairycowsolutions@alltech.com.

\section{References}

Del Pino A and Hernández J 2002. Ciclaje de fosforo por animals bajo pastoreo en campo natural y mejoramientos con leguminosas sobre suelos de basalto. Agrociencia 2, 47-52.

Dou Z, Knowlton K, Zhang G, Wu Z and Kohn R 2001. Lowering dietary P in dairy rations reduces the vulnerable $P$ fraction in manure. Journal of Dairy Science 84 (suppl. 1), 254.

Dou Z, Knowlton KF, Kohn RA, Wu Z, Satter LD, Zhang G, Toth JD and Ferguson JD 2002. Phosphorus characteristics of dairy feces affected by diets. Journal of Environmental Quality 31, 2058-2065.

Haan MM, Russell JR, Powers WJ, Kovar JL and Benning JL 2006. Grazing management effects on sediment and phosphorus in surface runoff. Rangeland Ecology and Management 59, 607-615.

Hill SR, Knowlton KF, Kebreab E, France J and Hanigan MD 2008. A model of phosphorus digestion and metabolism in the lactating dairy cow. Journal of Dairy Science 91, 2021-2032.

Karn JF 2001. Phosphorus nutrition of grazing cattle: a review. Animal Feed Science and Technology 89, 133-153.

Kebreab E and Vitti DMSS 2005. Mineral metabolism. In Quantitative aspects of ruminant digestion and metabolism (ed. J Dijkstra, JM Forbes and J France), pp. 469-486. CAB International, Wallingford, UK.

Kebreab E, Hansen AV and Strathe A 2012. Animal production for efficient phosphate utilization: from optimised feed to high efficiency livestock. Current Opinions in Biotechnology, 23, 872-877.

Kebreab E, France J, Sutton JD, Crompton LA and Beever DE 2005a. Effect of energy and protein supplementation on phosphorus utilization in lactating dairy cows. Journal of Animal and Feed Science 14, 63-77.

Kebreab E, Odongo NE, McBride BW, Hanigan MD and France J 2008. Phosphorus utilization and environmental and economic implications of reducing phosphorus pollution from Ontario dairy cows. Journal of Dairy Science 91, 241-246.

Kebreab E, Shah MA, Beever DE, Humphries DJ, Sutton JD, France $J$ and Mueller-Harvey I 2005b. Effects of contrasting forage diets on phosphorus utilisation in lactating dairy cows. Livestock Production Science 93, 125-135.

Kincaid RL, Garikipati DK, Nennich TD and Harrison JH 2005. Effect of grain source and exogenous phytase on phosphorus digestibility in dairy cows. Journal of Dairy Science 88, 2893-2902.

Knowlton KF and Herbein JH 2002. Phosphorus balance during early lactation in dairy cows fed diets varying in phosphorus content. Journal of Dairy Science 85, 1227-1236. 
Knowlton KF, Beede D and Kebreab E 2010. Phosphorus and calcium requirements of ruminants. In Phosphorus and calcium utilization and requirements in farm animals (ed. DMSS Vitti and E Kebreab), pp. 112-132. CAB International, Wallingford, UK.

Knowlton KF, Taylor MS, Hill SR, Cobb C and Wilson KF 2007. Manure nutrient excretion by lactating cows fed exogenous phytase and cellulase. Journal of Dairy Science 90, 4356-4360.

McDowell LR 1992. Minerals in animal and human nutrition. Academic Press, New York, 524pp.

National Research Council (NRC) 2001. Nutrient requirements of dairy cattle 7th edition. National Academy Press, Washington, DC.

Satter $L$ 2002. What goes in must come out - phosphorus balance on dairy farms. In Proceedings of the American Association of Bovine Practitioners, Madison, WI, pp. 125-130.

Satter LD and Wu Z 1999. New strategies in ruminant nutrition. In Proceedings of the Southwest Nutrition Management Conference, Phoenix, AZ, University of Arizona, Tucson, pp. 1-24.

Tamminga S 1996. A review on environmental impacts of nutritional strategies in ruminants. Journal of Animal Science 74, 3112-3124.
Ternouth JH 1990. Phosphorus and beef production in Northern Australia. Tropical Grasslands 24, 159-169.

Toor GS, Cade-Menun BJ and Sims JT 2005. Establishing a linkage between phosphorus forms in dairy diets, feces, and manures. Journal of Environmental Quality 34, 1380-1391.

Valk H, Sebek LBJ and Beyen AC 2002. Influence of phosphorus intake on excretion and blood plasma and saliva concentrations of phosphorus in dairy cows. Journal of Dairy Science 85, 2642-2649.

Winsten JR, Kerchner CD, Richardson A, Lichau A and Hyman JM 2010. Trends in the Northeast dairy industry: large-scale modern confinement feeding and management-intensive grazing. Journal of Dairy Science 93, 1759-1769.

Withers PJA, Hodgkinson RH, Adamson H and Green G 2007. The impact of pasture improvement on phosphorus concentrations in soils and streams in an upland catchment in Northern England. Agriculture Ecosystems and Environment 122, 220-232.

Wu Z, Satter LD and Sojo R 2000. Milk production, reproductive performance, and fecal excretion of phosphorus by dairy cows fed three amounts of phosphorus. Journal of Dairy Science 83, 1028-1041. 